\title{
Latin American Perceptions of Regional Identity and Leadership in Comparative Perspective*
}

Janina Onuki(1), Fernando Mouron(2) and Francisco Urdinez(3)**

\section{Abstract}

Public opinion plays a growing role in foreign policy formation in democratic societies. In this study, we use survey data from The Americas and the World project to establish whether Latin Americans share a common regional identity, and regard Brazil as a regional leader. Our results indicate that the majority of Brazilians do not identify themselves as Latin Americans. Moreover, while they believe their country is the most suitable candidate for regional leadership, they are unwilling to bear the costs of assuming such a role. Our study also explores perceptions of regional identity and Brazilian leadership in other Latin American countries, based on their own respective power aspirations. It shows that less powerful Latin American nations recognise Brazil as a regional leader, but citizens in middle powers, like Argentina and Mexico, still believe their countries should play a prominent regional role.

Keywords: Latin America, Public Opinion, Foreign Policy, Collective Identity, Regional Leadership, Brazil.

\footnotetext{
* Received on 30 October 2015 and approved for publication on 14 January 2016.

** (1) Universidade de São Paulo, São Paulo, SP, Brazil, janonuki@ usp.br; (2) Universidade de São Paulo, São Paulo, SP, Brazil, and King's College, London, England, fernandomouron@usp.br; (3) Universidade de São Paulo, São Paulo, SP, Brazil, and King's College, London, England; urdinez@usp.br.
} 


\section{Janina Onuki, Fernando Mouron and Francisco Urdinez}

\section{Introduction}

Given its unique role in holding political leaders to account, public opinion has become one of the most important factors influencing foreign policy-making in democratic societies (Sobel 2001; Foyle 2004). Moreover, foreign policy issues are featuring increasingly prominently in national debates and electoral campaigns (Holsti 1992). As a result, scholars and policy-makers alike have recently taken a closer interest in popular perceptions of foreign policy and foreign affairs (Faria 2008).

Considering this background, the purpose of this study is to record and analyse public opinion in various Latin American countries in respect of regional politics. It is based on survey results that have not yet been released, or utilised in any other study. More specifically, the study aims at analysing the extent to which the citizens of various Latin American countries acknowledge a common regional identity, and their perceptions of regional leadership. Our project stems from extensive literature on Brazilian foreign policy and regional leadership, which we will discuss in depth. As regards the theoretical premises of the study, we assume that two conditions are necessary for regional integration to move forward: countries must believe that they belong to a common region; and recognised regional leaders should be prepared to act as regional paymasters (Ikenberry 1996).

We examine the interconnections between these issues using data from a survey conducted in seven Latin American countries, namely Argentina, Brazil, Chile, Colombia, Ecuador, Mexico and Peru. This survey is the latest conducted under The Americas and the World (TAW), an ongoing research project aimed at studying public opinion and political culture in the Americas on key issues in foreign policy and international relations. ${ }^{1}$ It is led by the Mexican Centre for Research and Teaching in Economics (CIDE), which collaborates with selected universities in all seven countries relevant to our study. ${ }^{2}$ The survey samples were representative of each country's 
population, and sample sizes conformed with strict methodological criteria. $^{3}$

We chose the TAW project data as the basis of our study because it has not yet been used in published academic papers, ${ }^{4}$ and because of its high quality. TAW addresses foreign policy themes that other projects, such as the often cited Latinobarometer and the Latin American Public Opinion Project (LAPOP) do not. Furthermore, our data complements the findings of previous qualitative studies (Belem Lopes and Faria 2015), as well as theories by prominent scholars (Sorj and Fausto 2011). For example, our findings chime with the valuable qualitative work of Souza (2009), based on interviews with members of the Brazilian elite (political, diplomatic and academic) about Brazilian foreign policy, and published by the Brazilian Centre for International Relations (CEBRI).

The findings presented in this article are threefold. We first observe that respondents in six of the seven countries identified themselves most strongly as Latin Americans, with Brazil the prominent exception. Bethell (2010) has identified Brazilian exceptionalism through a historiographical analysis, but this has not previously been confirmed by survey data. Next, we confirm that Brazilians believe their country to be the most suitable candidate for the role of regional leader, but are reluctant to carry the costs of such a role. Finally, but equally importantly, we show that while citizens of smaller countries recognize Brazil's regional leadership role, Argentinians and Mexicans regard their own countries as the rightful regional leader, which points to an emerging but previously unidentified trend in Latin American foreign relations.

Our paper is structured as follows. In the first section we discuss the concept of collective identity, and present a brief summary of perceptions of Latin American regional identity in the seven countries under review emanating from the TAW survey. Next, we analyze Brazil's role in Latin America, linked to the concept of regional 
leadership, before examining how Brazilians perceive their country's global and regional role. Following this, we examine perceptions of Brazilian leadership in other Latin American countries, drawing a distinction between small and middle regional powers. Finally, we compare our findings with those reached in other studies.

\section{Latin American collective identity and Brazilian exceptionalism}

We begin this section by assuming that 'region' is not an objective idea but a politically contingent - and thus contested - phenomenon (Hurrell 2007:241). In this framework, the geographical boundaries of a region are not obvious or natural, but exist as the result of a political struggle emanating from the perceptions, interests, values and identities of key players in the region (Spektor 2010: 31). Therefore, under a constructivist approach, 'regionalism' can be explained in terms of the distribution of ideas used by states in pursuit of their own regionalist projects (Pietro 2003: 274).

Any investigation of collective identity must take into account that knowledge is an infinite construction which renews itself in a constant socialisation process (Legro 2000). As such, in the absence of a uniform cultural essence, we conceptualise collective identity in terms of never-ending changes in interpretation, renewal and criticism (Chanady 1994). Furthermore, the factors determining actors' interests, motives, ideas and identities are not predetermined exogenous values, but rather malleable constructs put in play by a multitude of agents that adapt to others' actions and changing contexts (Hettne and Söderbaum 2000: 460).

With this as a foundation, we draw on Wendt's seminal work to affirm that for collective identity to exist, it must possess a common in-group identity or so-called 'us' feeling by redefining the boundaries of 'Self' and 'Other' (Wendt 1999). In other words, a regional identity refers to the shared perception of belonging to a 
particular community (Pietro 2003: 275), while for states, developing a regional identity or a shared sense of belonging is an essential part of institutionalising regional co-operation (Hook and Kearns 1999).

The notion of a Latin American region has deep historical roots. In the age of independence, some politicians in Spanish America tried to build a confederation of former colonies, and establish a single nation. ${ }^{5}$ However, the concept of 'Latin America' only emerged much later when French intellectuals attempted to justify French imperialism in México under Napoleon III (Ardao 1980). Since then two principal factors have helped to forge a collective identity among Latin American countries: the wars of independence, which created a sense of 'We, the colonies' against the 'Others, the conquerors and central powers'; and opposition to the growth of North American power since the early $20^{\text {th }}$ century (Eakin 2004).

However, the end of the Cold War and the onset of the $21^{\text {st }}$ century have completely changed regional dynamics. Over the past three decades, regional trade blocs have sprung up, American influence has diminished (Saraiva 2012), and the distribution of power within the region has changed (Schenoni 2012). Thus, given the rupture in the region's traditional dynamics, there is a need to identify the degree to which modern-day Latin Americans have a sense of regional identity, or regional belonging.

To this end, we used the TAW data to identify perceptions of regional identity across the seven countries in question. The sample comprises 10544 observations, and we used them to calculate the percentage of respondents in each country who regard themselves as 'Latin American'. This identifier was offered as an option together with 'South American', 'world citizen', the respective country demonyms (Chilean, Argentinian, etc), and trade blocs such as Mercosur or the Andean Community (hereafter CAN) (see Appendix I). 


\section{Janina Onuki, Fernando Mouron and}

Francisco Urdinez

The findings are depicted in Figure 1. It reveals that 'Latin American' was the strongest identifier among participants in most countries. On average, $43 \%$ of all respondents think of themselves as Latin Americans first and foremost, ranging from 59\% in Colombia to $38 \%$ in Chile.

\section{Figure 1:}

Self-identification as 'Latin American' by respondents in seven countries (\%)

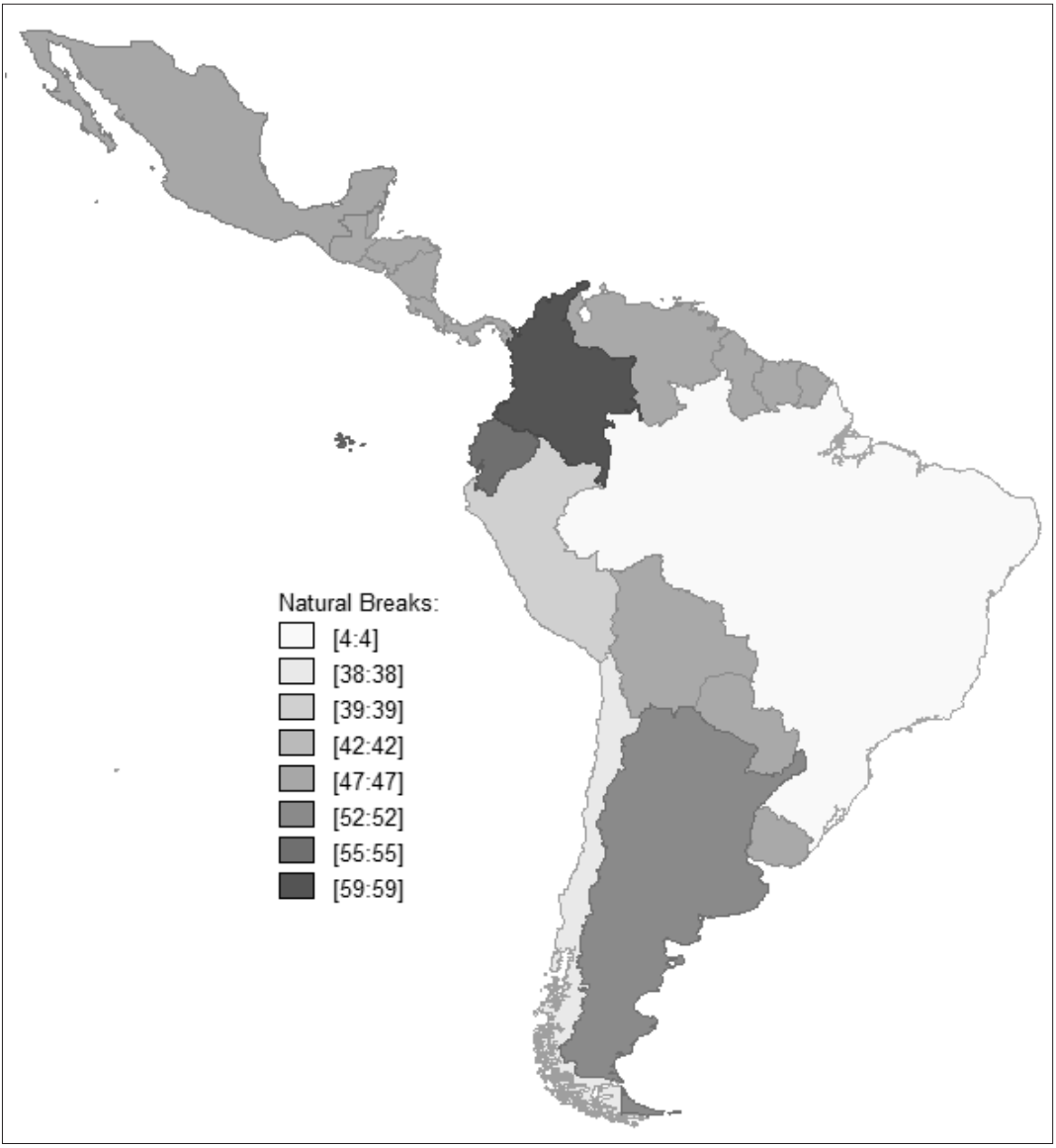

Source: Compiled by the authors from TAW data, using GeoDa mapping software. 
While the citizens of all the Spanish-speaking countries in the sample expressed a degree of 'Latin American-ness', Brazil is an outlier, with only $4 \%$ of respondents identifying themselves in this way. To break down these results further, $79 \%$ of Brazilian respondents identified themselves as 'Brazilian', followed by 'world citizen' (13\%), Latin American (4\%), and South American (1\%).

This is an interesting result, considering that demonyms were not among the top three choices in any of the other samples. In Argentina, Chile, Colombia, Ecuador and Peru, 'Latin American' was followed by 'South American' and 'world citizen', while in Mexico, it was followed by 'world citizen' and 'North American'.

Therefore, the data shows clearly that the self-identification of Brazilians diverge from those of their Latin American counterparts, which confirms Bethell's thesis of 'Brazilian exceptionalism'. Bethell emphasises the country's unique colonial heritage, intellectuals' long-held dismissal of Brazil as a Latin American country, and the reluctance of consecutive Brazilian military governments to assume a leadership position as factors that have historically negated a sense of regional belonging (Bethell 2010: 481).

In turn, since the monarchic period, Brazilian diplomats have sought to consolidate Brazil's image as a continental country - an identity that has formed part of Itamaraty's motto as the 'first driver of Brazilian foreign policy' (Lafer 2011). This identity, based on Brazil's continental dimension, its linguistic difference, and its role in the international arena, are elements that have influenced Brazilian diplomacy since its independence.

Brazil's outlier status raises a fundamental question for international relations: can a country lead a region with which its citizens do not identify? To put this issue in perspective, could the European Union exist if German or French citizens did not regard themselves as 
Europeans in the first instance? This issue, which is central to Itamaraty's approach to Brazil's role in Latin America, have not yet been empirically studied by scholars. Therefore, in the following section we ask ourselves: could Brazilians' lack of identification with Latin America be linked to their perceptions of their country's regional leadership role?

\section{Brazil's rise and its ambiguous position in Latin America}

Global powers recognise Brazil not only as a relevant player in the international arena, but also as an actor able to influence the international political agenda (Scrim 2012). This status is not derived from its material resources, but from its leadership role in multilateral forums (Cervo 2010; Hirst 2015). It is not surprising, therefore, that a large majority of Brazilians believe their country is globally significant (see Figure 2).

\section{Figure 2:}

Perceptions of Brazil's international relevance among Brazilian respondents

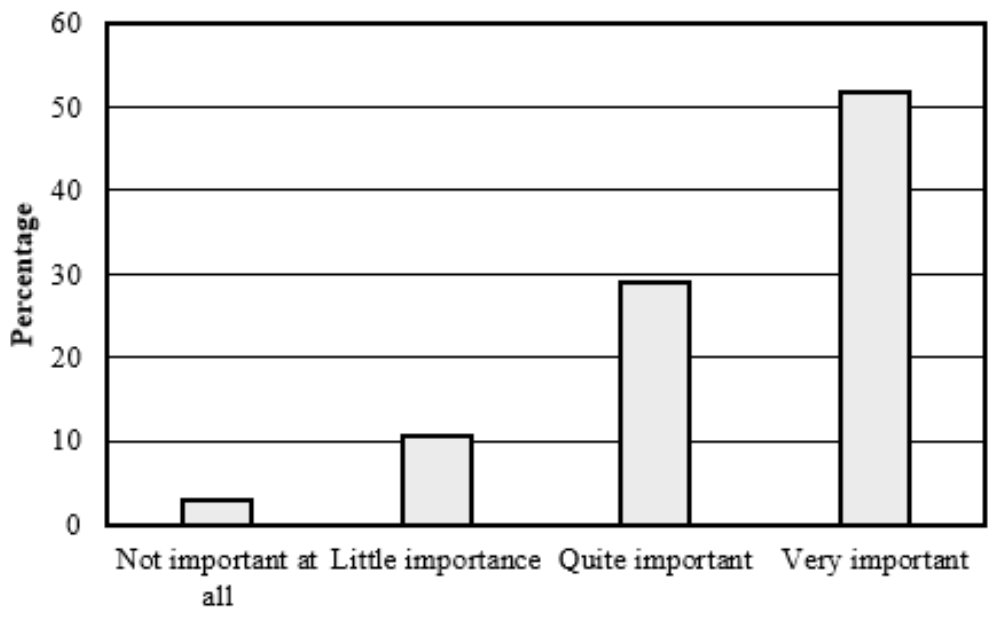

Source: Compiled by the authors from TAW data. 


\section{Latin American Perceptions of Regional Identity and Leadership in Comparative...}

Brazilians are clearly enthusiastic about the international prominence their country has achieved in recent decades, which explains why more than half of respondents approve of its current foreign policy (Appendix II), even when a majority disagreed with the government in power at the time of the survey ${ }^{6}$ (Appendix III; see Figure 3).

\section{Figure 3:}

Approval of Brazilian foreign policy by Brazilian respondents

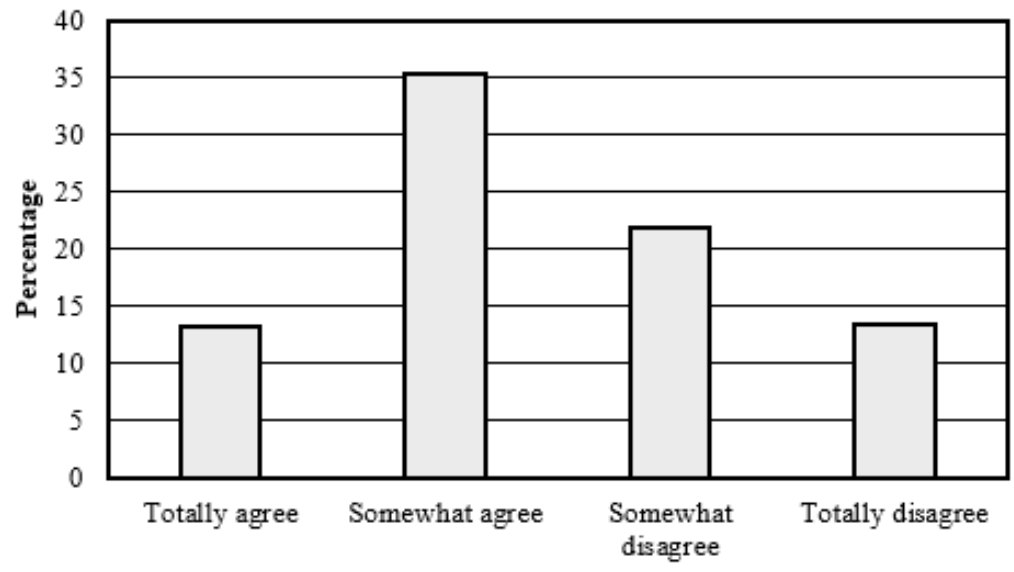

Source: Compiled by the authors from TAW data.

Despite Brazil's new-found global status, including its membership of the BRICS alliance, scholars are divided about its regional role. Some argue that Brasilia is the current regional leader because it has the will to act as regional paymaster, and its leadership status is accepted by its counterparts (Saraiva 2010; Teixeira 2011; Pinheiro and Gaio 2014). Others believe Planalto is not prepared to shoulder the costs of regional leadership (Varas 2008; Flemes 2009), as its position would be contested by the other regional middle powers, namely Argentina, Chile and Venezuela (Flemes and Wojczewski 2010).

Reviving Ikenberry's (1996) classic definition of regional leadership, a regional leader must possess the aspirations and 
resources necessary to assume such a position; and must be recognized and accepted by its neighbors, especially other regional middle powers. Using this definition as a guide, we now examine whether Brazilians believe there are inherent costs to assuming a regional leadership role. We then compare these perceptions with those in the other countries under review.

\section{The costs and benefits of regional leadership}

The late $20^{\text {th }}$ century brought changes such as monetary stability, economic liberalisation, democratisation, and increased Brazilian participation in international and regional agreements that worked with ruptures in the international system to end Itamaraty's monopoly of Brazilian foreign policy-making (Milani and Pinheiro 2013: 26). Coupled with demands by other government agencies (including the Ministry of Finance, the Ministry of Industry and Trade, and the Ministry of Agriculture) as well as civil society actors (including trade unions, business associations, academics, and NGOs), the foreign policy process became more and more complex. In this context, Brazilian voters began to connect the results achieved by the current government's foreign policy with their sense of personal well-being (Belem Lopes and Faria 2014). This phenomenon helped to create what Belem Lopes calls a "public agenda of its own', for which Itamaraty has increasingly been called to account (Belem Lopes 2011:69). Another major factor has been the internet explosion, ${ }^{7}$ which has enabled members of the public to take a closer interest in foreign affairs, ${ }^{8}$ thereby turning public opinion into an important element to consider in analysing foreign policy.

Taking this new reality into account, we first trace citizens' views of what the priorities of Brazilian foreign policy should be (Figure 4). When asked which regions Brazil should pay more attention to, Latin 


\section{Latin American Perceptions of Regional Identity and Leadership in Comparative...}

America did not emerge as the most popular choice; indeed, the first choice was Africa (24\%), followed by Latin America (16\%) and Europe (14\%). By contrast, at an average of $42 \%$, Latin America was the most popular choice in all the other countries. In figure 4 we have expressed these differences in terms of standard deviations.

\section{Figure 4:}

Choice of Latin America as the most important foreign policy priority

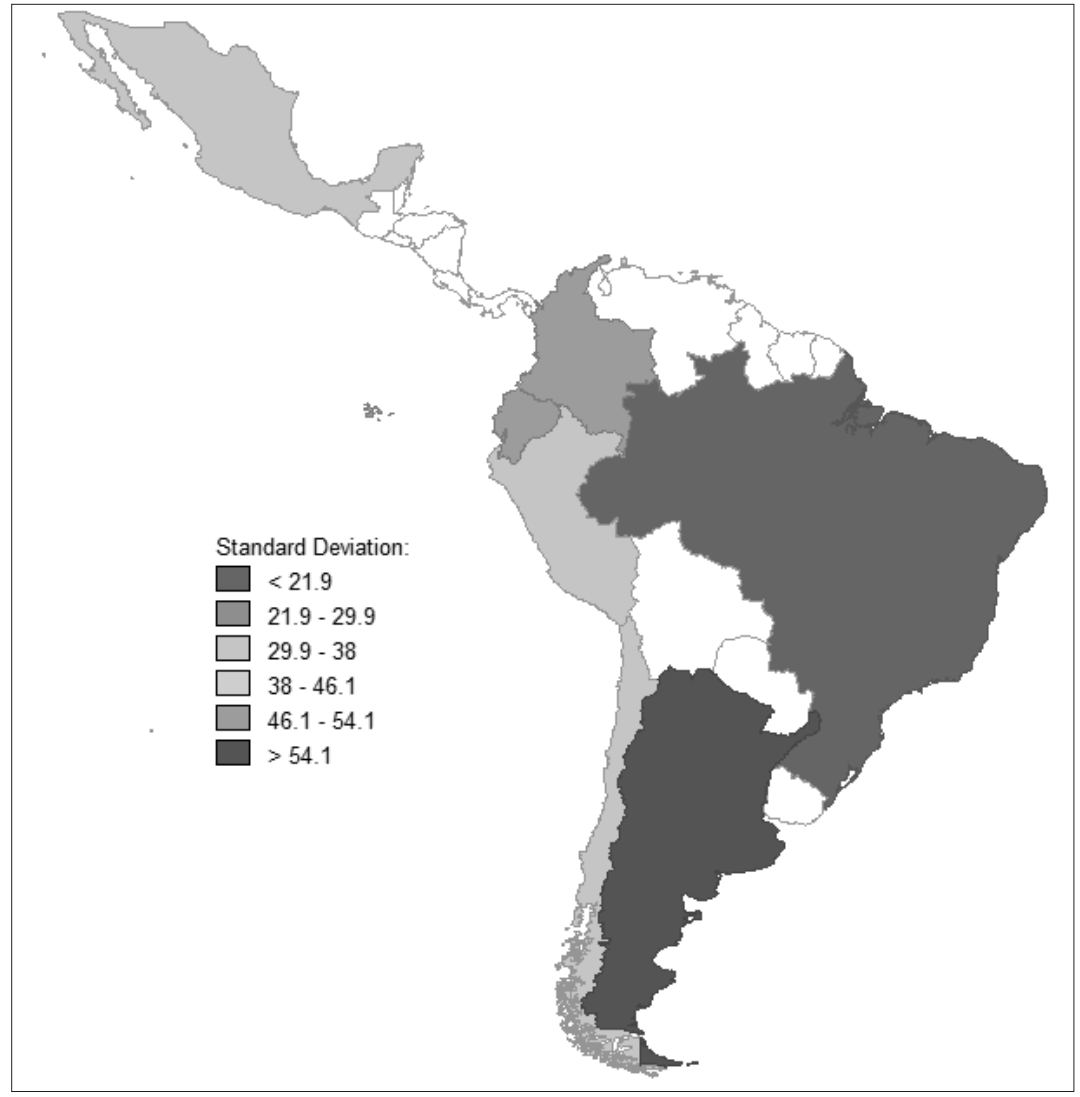

Source: Compiled by the authors from TAW data, using GeoDa mapping software.

Figure 5 combines Figures 1 and 4 into a two-axis graph, which reveals a high positive correlation between citizens' identification as 


\section{Janina Onuki, Fernando Mouron and}

Francisco Urdinez

Latin American and their perceptions of the region's global importance. This graph has three distinct features: (a) a group of countries (Colombia, Ecuador and Argentina) in which almost half of the population identify themselves as 'Latin American', and believe the region should be prioritised in their country's foreign policy; (b) a second group of countries (Mexico, Peru and Chile) with moderate values along both axes which place them in the middle of the figure; and (c) the outlier Brazil, which scored the lowest on both axes, and therefore deserves special attention.

\section{Figure 5:}

Identification as Latin American and Latin America as a foreign policy

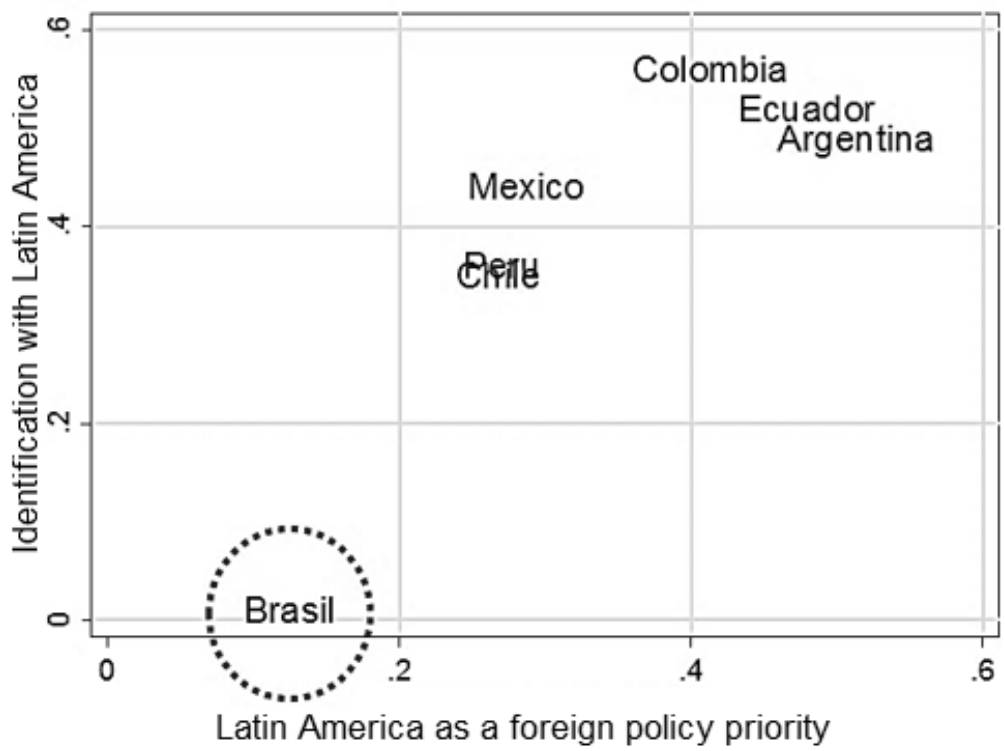

Source: Compiled by the authors using TAW data.

As noted previously, a would-be regional leader must have the will to act as regional paymaster, and shoulder the costs of doing so. These 'expenses' can be military, economic or social. The TAW survey addressed the issue of military expenses by asking respondents whether they believed their country should intervene in a regional 


\section{Latin American Perceptions of Regional Identity and Leadership in Comparative...}

military crisis (Appendix V). As Figure 6 shows, most Brazilians reject the idea of their country playing an active role in a regional conflict. This finding is consistent with Brazil's historical position of non-intervention in the domestic affairs of other states (Burns 1967). However, as Miriam Gomes Saraiva suggests, the concept of non-intervention should be nuanced due to the many other ways in which a state could participate in regional affairs, such as funding infrastructure projects, engaging in technical co-operation, and prioritising bilateral relations (Saraiva 2010: 161). We group all these potential activities into what we call economic leadership.

\section{Figure 6:}

Brazilian military intervention in a regional crisis

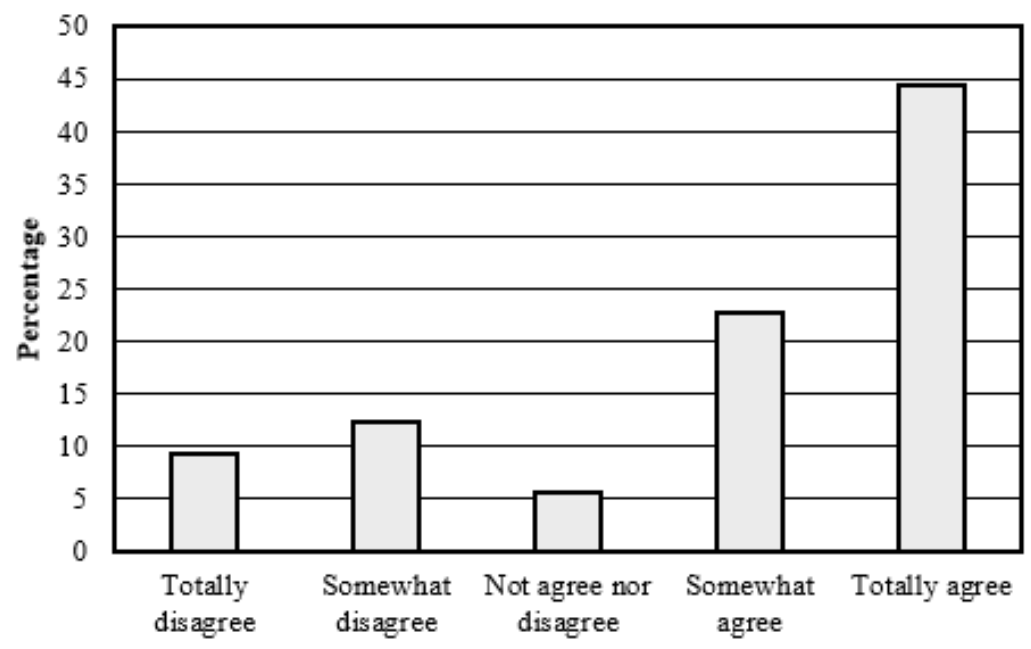

Source: Compiled by the authors from TAW data.

In order to establish whether Brazilians support the idea of Brazil 'leading with the purse', we considered a survey question whether respondents agreed with their country helping less developed nations in the region (Appendix VI). At first glance, it appears that Brazilians believe their country should help others economically, as $65 \%$ of respondents agreed with this statement. However, this score is the 
lowest of all countries. In fact, the high scores in other countries can be explained by what is known in public opinion literature as the 'social desirability bias', that is, when respondents respond to moral questions in ways which they consider to be socially and politically correct. This hides their real preferences, and thus distorting collective public sentiment (Berinsky 1999: 1209). ${ }^{9}$ As the specialised literature suggests, when alternatives such as indirect questioning, the use of forced-choice items, or proxy subjects are non-viable (Nederhof 1985; Fisher 1993), it is better to avoid the pitfalls of absolute analysis, opting instead for a comparison with other cases, as we have done (see Figure 7).

\section{Figure 7:}

Economic assistance to less developed countries in the region

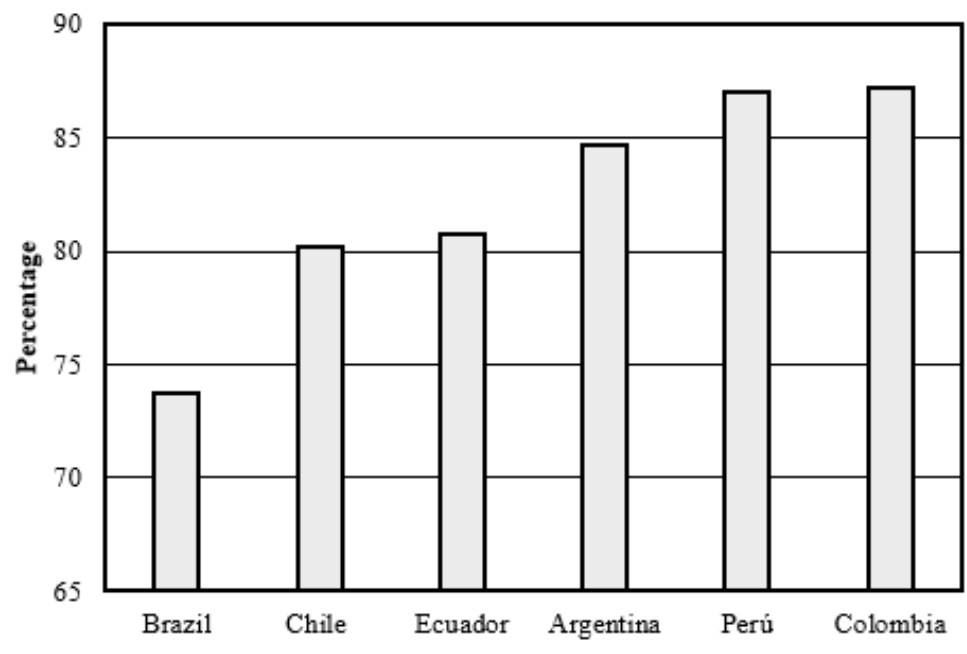

Source: Compiled by the authors from TAW data.

We believe Brazil's reluctance to assist its neighbors financially is partly due to its record in respect of human development, which lags behind those of 'smaller' countries despite Brasilia's greater material resources. ${ }^{10}$ Here, we agree with Malamud, who argues that it would be virtually impossible to 'sell' to a Brazilian audience the 
merits of large money transfers between Brasilia and neighboring countries, as Argentina, Chile and Uruguay rank consistently higher in terms of GDP per capita and human development than Brazil (Malamud 2011: 5).

It is worth noting that Brazil is not the only instance of citizens in a leading country expressing reluctance to assist neighboring states financially, and play a leading regional role. To put this argument in perspective, during the recent financial crisis in the European Union (EU), most polls reported that German citizens were opposed to Germany assisting other EU members financially. Germans also favoured the 'Grexit' proposal (the withdrawal of Greece from the EU). In this regard, Bechtel Hainmueller and Margalit (2014) conducted an experimental survey of German opinions about potential contributions to a financial rescue fund. While $38.5 \%$ of respondents favoured the idea, $61 \%$ were against it.

Finally, as regards the social aspect of regional leadership, Brazilians were asked whether the free movement of people among Latin American countries would be desirable (Appendix VII). In Brazil, $60 \%$ of those interviewed disagreed, or strongly disagreed (see Figure 8). This is an interesting finding, given that Brazil has not been exposed to a major migratory crisis such as those in Europe or the United States. Indeed, according to official data, only $1.8 \%$ of the Brazilian population are immigrants, ${ }^{11}$ a low level compared to powerful EU countries such as Germany or the United Kingdom, which have immigrant populations of $11.9 \%$ and $12.4 \%$ respectively.

In this section, after recalling the classic definition of leadership, we explored how Brazilians regard Latin America compared to other world regions, as well as their reaction to their country carrying the costs of leadership in Latin America. The data shows Brazilians feel detached from the region, both in terms of investment in its 
Janina Onuki, Fernando Mouron and

Francisco Urdinez

Figure 8:

Brazilian support for the free movement of people in Latin America

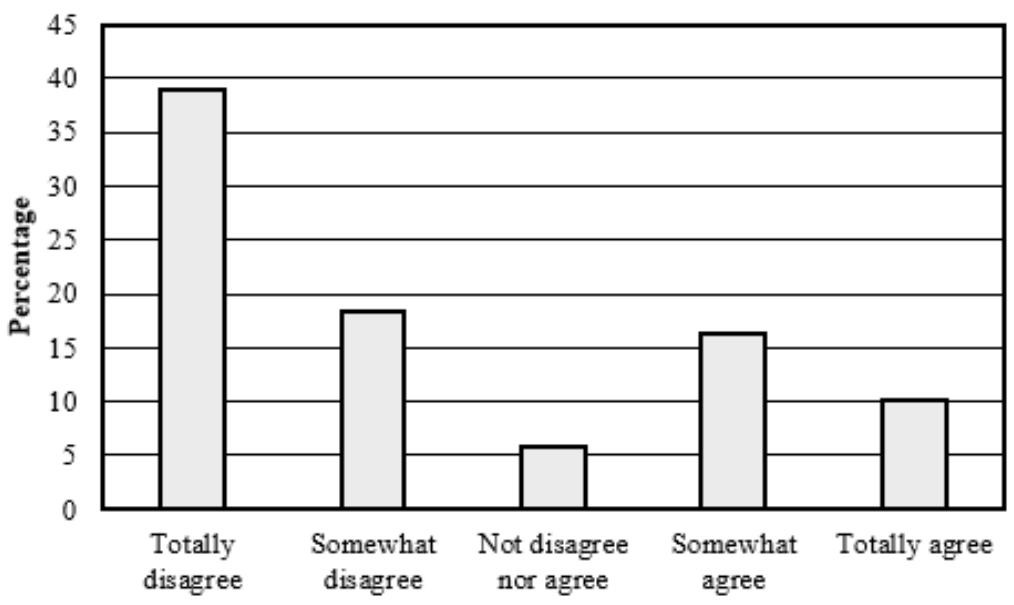

Source: Compiled by the authors from TAW data.

well-being and its relevance for Brazilian foreign policy. The next section focuses on the other side of the coin, namely the appeal of Brazilian leadership to people in other Latin American countries.

\section{A leader with insignificant followers}

From a constructivist standpoint, the idea of leadership is not merely an entitlement but a construction that depends on both the leader's own aspirations and the recognition of its followers. As Wehner (2015) puts it, to lead means that the leader's initiatives are based on a symbolic legitimacy that exceeds its material capabilities, which explains in turn why other regional nations consent to be led.

If we applied this reasoning to our analysis, we could argue that Brazil's role would not exclusively depend on its self-awareness as the dominant material power in the region. It would also depend on other nations' perceptions of themselves, and whether they recognise 


\section{Latin American Perceptions of Regional}

Identity and Leadership in Comparative...

Brazil's leadership status (Schirm 2012). Therefore, Brazil's leadership would depend on whether secondary powers support or resist its desire for greater global power (Wehner 2015: 438).

Because of regional power rivalries and a relative resource deficit, Malamud (2011) defines Brazil as a 'leader without followers', or a country likely to fashion itself as a middle-level global power before gaining recognition as a regional leader (Malamud and Rodriguez 2013). Similarly, other authors have highlighted Brazil's difficulty in being the de facto a regional leader (Burges 2015; Flemes and Wehner 2015). Brazil has eschewed the power-political game that is central to realist theory (Hurrell 1998), acting instead as a 'consensual hegemon' that creates consensus through the inclusion of seemingly contradictory priorities that shape positive outcomes (Burges 2008).

In Section 2 we showed how Brazilians feel detached from the region, and in section 3 we examined their reluctance to see their country play the role of regional leader and paymaster. We will now focus on opinions in those countries which would be led by Brazil, notably their attitudes to possible Brazilian regional leadership. Respondents in each country were asked which two countries should represent Latin America in the United Nations Security Council (Appendix VIII). Brazil emerged as a clear first choice, followed by Argentina and Chile (see Figure 9).

These figures are important for our argument, since they reveal expectations of Brazilian leadership in smaller Latin American countries. In short, the data shows how Brasilia can be a voice for the region. Brazil's economic growth over the past 15 years, combined with its sheer size (it is the region's largest country in terms of GDP, population, and geographical area) makes it a natural candidate to represent smaller, weaker Latin American countries. However, Mexicans and Argentinians still believe this role should be assumed 
Figure 9:

Most suitable representative in the UN Security Council

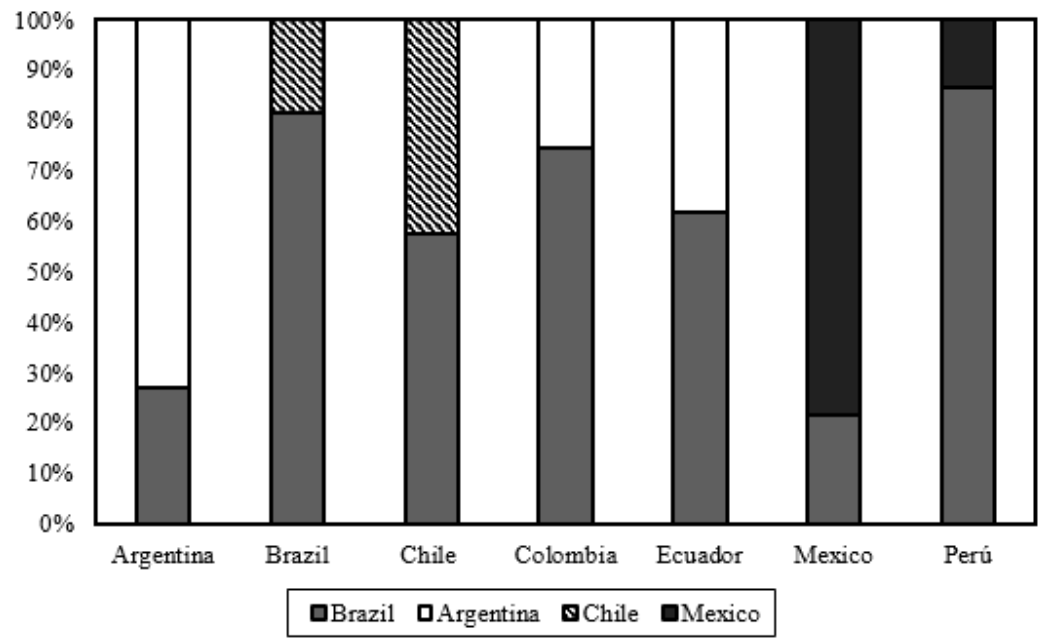

Source: Compiled by the authors from TAW data.

by their own countries, lending credence to the argument that the historical rivalry between Argentina and Brazil, together with Mexico's increasing regional stature, interfere with Brazil's leadership ambitions.

Historically, Argentina has competed with Brazil over regional pre-eminence. They have passed through several periods of hostile relations, but tensions have diminished as the disparity in material resources between them have grown. Since the 1980s, when Brazil reached a clear material superiority, Argentina has avoided direct confrontation with its neighbor, employing a strategy of ‘soft-balancing' Brazilian power instead (Merke 2015).

As noted by Russell and Tokatlian, and confirmed by other public surveys, ${ }^{12}$ Argentinian specialists as well as citizens consider Brazil to be their country's main strategic partner (Russell and Tokatlian 2011: 250-251). Despite this perceived alliance, our findings show 
that the historical rivalry between these countries has not been followed by a new co-operative array, but rather one of mutual coexistence (Winand 2015: 69-70). Thus Argentinians may regard Brazil as their main ally, but are also wary of becoming dependent on their neighbor. This would explain why they seek to maintain their own aspirations in the international arena without conceding much regional representation to Brazil.

Referring to Mercosur, Malamud argues that Argentina's political ambitions are similar to Brazil's, as it has continued to fan economic grievances against its bigger neighbour. These complaints have given rise to periods of protectionist behaviour that have sometimes hindered further regional integration (Malamud 2011: 11). One seemingly contradictory element that deserves mention is the Brazilian-driven creation of the influential Union of South American Nations (UNASUR), and Argentina's support for it (Teixeira 2011). Some authors have argued that Buenos Aires has embraced this initiative for the very purpose of limiting Brazil's regional leadership aspirations, and to curb unfettered Brazilian growth (Nolte 2010: 895).

In turn, a recent experimental survey by Mouron and Urdinez (2016) shows that Argentinian citizens are sensitive to new information about Brazil's growing power. The main finding is that Argentinians tend to overestimate the power of their own country when compared to Brazil, and are sensitive to situations that emphasize the disparity in power between the two countries. When presented with this type of information, Argentinians tend to say their country should avoid aligning with Brazil and rather seek new regional partners, in order to counterbalance Brazil's growing power.

When the region in question is changed to Latin America and not South America, Mexico, rather than Argentina, is the country that poses the biggest challenge to Brazilian leadership (Wehner 2015: 
440; Malamud and Gardini 2012). Mexico has a strong influence over Caribbean countries -which Brazil has failed to achieve-and strong relations with the United States. Moreover, Mexico has belonged to the OECD since 1994, while Brazil is still on the waiting list. ${ }^{13}$ The portrait that emerges is that Mexicans regard Brazil as a distant rival in cultural (mainly due to the language barrier) and geographical terms. Mexicans still see themselves as the region's 'face', which explains why they do not recognize Brazilian leadership. We believe this phenomenon is reflected in Figure 9, which shows that more than $75 \%$ of Mexican interviewees thought Mexico to be the best candidate for a permanent seat in the UN Security Council.

On the other hand, Brazilian responses also deserve to be explored. Brazilian citizens regard their country as a natural candidate for a permanent seat in the UN Security Council, with more than $80 \%$ of those surveyed stating that Brasilia should occupy this position. However, as shown previously, Brazilians are reluctant to shoulder the implicit costs of regional leadership. Drawing on interviews with senior politicians rather than general opinion surveys, Malamud suggests that Brazil sees the region as a springboard to a global leadership position. In this sense, playing a leading role in Latin America would be a means to an end, which is reflected in the contradictory findings that this study discusses and explores more deeply in the following section.

\section{Discussion and conclusions}

Based on the growing relevance of public opinion to foreign policy-making, this study explores fresh empirical evidence to outline how Latin Americans in seven countries perceive regional politics and social demands. 
We find that people in six of the seven countries under review have a strong sense of regional belonging, with Brazil being the exception. We explore whether this lack of regional identification could stem from the issue of regional leadership, which is still contested. This uncertainty starts with Brazilians themselves, who are reluctant to sacrifice domestic economic and social resources to assist a region which they regard as less important than Africa, for example.

This reluctance to carry the costs of regional leadership stems from Brazil's historical position towards the region. At the start of the $20^{\text {th }}$ century, and towards the end of the Cold War, Brazilian diplomats believed the best way of improving their country's position in the international system was to remain isolated from regional affairs (Trikunas 2014: 10). As a result, until the mid-1980s, Brazilian elites and citizens in general viewed Latin America not as a larger construct of collective identity, but merely as the surrounding geographic landscape (Malamud and Rodriguez 2013: 174).

This detachment from Latin American identity, combined with efforts to block potential Mexican rivalry for regional leadership, resulted in the new regional concept of 'South America'. By eschewing a potential 'Latin American' identity for this new identity, Brazil tacitly acknowledged that it was unable to exert significant influence over the entire continent, and would therefore limit itself to a smaller area (Malamud 2011: 6). Since the start of the first Lula administration, when Marco Aurelio Garcia advised the president on international affairs, national development advocates have gained space within the Ministry of Foreign Affairs (Santos 2011: 159) and entrenched regional (that is, South American) integration as one of Brazil's foreign policy priorities (Vigevani and Cepaluni 2007; Amorim 2010). Despite these efforts, our findings show that Brazilians have not been won over by either of these notions, as they still believe their country is sui generis in the region. 
The results also confirm what Spektor and Flemes suggested in their non-empirical study five years ago, namely that members of the Brazilian public tend to perceive the region in terms of concerns and problems rather than benefits (Spektor 2010: 29). Moreover, they are also ambivalent about carrying the costs associated with regional leadership (Flemes 2009: 171). Although Brazil has been able to suppress the rise of regional challengers, it has not been able to persuade other middle Latin American powers, such as Argentina and Mexico, to back its own ascendancy to leadership (Trinkunas 2014: 27). Indeed, both those countries are trying to prevent any single country from 'representing' the whole region (Malamud 2011: 11-12). Most existing studies neglect the role of public opinion in other Latin American countries in determining Brazil's capacity to assume the role of regional power. Our study illustrates that neither Mexicans nor Argentinians readily recognise or accept Brazil's regional leadership (Wehner 2015).

Finally, drawing on a major, region-wide opinion survey -rather than the usual interviews with selected politicians and diplomats - presents a complementary picture to the world in which the latter operate. In this regard, our study complements other recent studies (Belem Lopes and Faria 2015; Sorj and Fausto 2011). As such, we believe our study contributes to the existing literature by including a largely neglected segment of the region which better reflects 'politically incorrect' opinions, and underlining the importance of public opinion in foreign policy-making.

\section{Acknowledgements}

We would like to thank the São Paulo Research Foundation, the Brazilian institution that has funded the last two TAW surveys, which were conducted by the International Relations Institute at the University of São Paulo. The foundation also provided financial support through grants 2013/23251-9, 2014/03831-3, 


\section{Latin American Perceptions of Regional \\ Identity and Leadership in Comparative...}

2015/12688-2, and 2015/12860-0. The results presented in this paper are the sole responsibility of the authors. We thank Gerardo Maldonado and Trent Boultinghouse for their suggestions and comments.

\section{References}

Amorim, Celso. 2010. 'Brazilian foreign policy under President Lula (2003-2010): an overview'. Revista Brasileira de Política Internacional, 53(SPE): 214-240.

Ardao, Arturo. 1980. Génesis de la idea y el nombre de América Latina (Vol 3). Caracas: Centro de Estudios Latinoamericanos Rómulo Gallegos.

Bechtel, Michael M, Jens Hainmueller and Yotam Margalit. 2014. 'Preferences for international redistribution: the divide over the Eurozone bailouts'. American Journal of Political Science, 58(4): 835-856.

Belem Lopes, Dawisson. 2011. 'A política externa brasileira ea 'circunstância democrática': do silêncio respeitoso à politização ruidosa'. Revista Brasileira de Política Internacional, 54(1): 67-86.

Belem Lopes, Dawisson and Carlos A Pimenta de Faria. 2014. 'Eleições presidenciais e política externa brasileira'. Estudos Internacionais: revista de relações internacionais da PUC Minas, 2(2): 139-147.

2015. 'Foreign policy cycles in Latin American democracies'. Proceedings of the Latin American Studies Association Annual Meeting, 2015, San Juan: LASA, 1-20.

Berinsky, Adam J. 1999. 'The two faces of public opinion'. American Journal of Political Science: 1209-1230.

Bethell, Leslie. 2010. 'Brazil and "Latin America"'. Journal of Latin American Studies, 42(3): 457-485.

Burges, Sean W. 2008. 'Consensual hegemony: theorizing Brazilian foreign policy after the Cold War'. International Relations, 22(1): 65-84. 


\section{Janina Onuki, Fernando Mouron and}

Francisco Urdinez

2015. 'Revisiting consensual hegemony: Brazilian regional leadership in question'. International Politics, 52(2): 193-207.

Burns, E Bradford. 1967. 'Tradition and variation in Brazilian Foreign Policy'. Journal of Inter-American Studies 9(2): 195-212.

Cervo, Amado L. 2010. 'Brazil's rise on the international scene: Brazil and the World'. Revista Brasileira de Política Internacional, 53(SPE): 7-32.

Chanady, Amaryll Beatrice (ed). 1994. Latin American Identity and Constructions of Difference. Minnesota: University of Minnesota Press.

Eakin, Marshall C. 2004. 'Does Latin America have a common history?' Vanderbilt e Journal of Luso-Hispanic Studies, 1: 29-49.

Pimenta da Faria, Carlos A. 2008. 'Opinião pública e política externa: insulamento, politização e reforma na produção da política exterior do Brasil'. Revista Brasileira de Política Internacional, 51(2): 80-97.

Fisher, Robert J. 1993. 'Social desirability bias and the validity of indirect questioning'. Journal of Consumer Research, 303-315.

Flemes, Daniel. 2009. 'Brazilian foreign policy in the changing world order'. South African Journal of International Affairs, 16(2): 161-182.

Flemes, Daniel and Leslie Wehner. 2015. 'Drivers of strategic contestation: the case of South America'. International Politics, 52(2): 163-177.

Flemes, Daniel and Thorsten Wojczewski. 2010. 'Contested leadership in international relations: power politics in South America, South Asia and Sub-Saharan Africa'. GIGA Working Paper 121. Available at http://giga.hamburg/ en/publication/contested-leadership-in-internationalrelations-power-politics-in-south-america-south [accessed on 1 September 2015].

Foyle, Douglas C. 2004. 'Leading the public to war? The influence of American public opinion on the Bush administration's decision to go to war in Iraq'. International Journal of Public Opinion Research, 16(3): 269-294.

Hettne, Björn, and Fredrik Söderbaum. 2000. 'Theorising the rise of regionness'. New Political Economy, 5(3): 457-472.

Hirst, Monica. 2015. 'Emerging Brazil: the challenges of liberal peace and global governance'. Global Society, 29 (3): 359-372. 


\section{Latin American Perceptions of Regional Identity and Leadership in Comparative...}

Holsti, Ole, R. 1992. 'Public opinion and foreign policy: challenges to the Almond-Lippmann Consensus Mershon Series: research programs and debates'. International Studies Quarterly, 36(4): 439-466.

Hook, Glenn and Ian Kearns (eds). 1999. Subregionalism and World Order. London: Macmillan.

Hurrell, Andrew. 1998. 'An emerging security community in South America?' In Manuel Adler and Michael Barnett (eds). Security Communities. Cambridge Cambridge University Press: 228-264.

2007. On Global Order: Power, Values, and the Constitution of International Society. Oxford: Oxford University Press.

Ikenberry, John G. 1996. 'The future of international leadership'. Political Science Quarterly, 111(3): 385-402.

Krumpal, Ivar. 2013. 'Determinants of social desirability bias in sensitive surveys: a literature review'. Quality \& Quantity, 47(4): 2025-2047.

Lafer, Celso. 2001. A Identidade Internacional do Brasil e a Política Externa Brasileira: Passado, Presente e Futuro. São Paulo: Perspectiva.

Legro, Jeffrey W. 2000. 'The transformation of policy ideas'. American Journal of Political Science, 44(3): 419-432.

Malamud, Andrés. 2011. 'A leader without followers? The growing divergence between the regional and global performance of Brazilian foreign policy'. Latin American Politics and Society, 53(3): 1-24.

Malamud, Andrés and Luca G Gardini. 2012. 'Has regionalism peaked? The Latin American quagmire and its lessons'. The International Spectator, 47(1): 116-133.

Malamud, Andrés and Júlio C Rodriguez. 2013. 'Com um pé na região e outro no mundo: O dualismo crescente da política externa brasileira'. Estudos Internacionais: revista de relações internacionais da PUC Minas, 1(2): 167-184.

Merke, Federico. 2015. 'Neither balance nor bandwagon: South American international society meets Brazil's rising power'. International Politics, 52(2): 178-192. 


\section{Janina Onuki, Fernando Mouron and}

Francisco Urdinez

Milani, Carlos R. and Leticia Pinheiro. 2013. 'Política externa brasileira: os desafios de sua caracterização como política pública'. Contexto Internacional, 35(1): 11-41.

Morales Castillo, Rodrigo, Gerardo Maldonado and Jorge A Schiavon. 2015. 'To know or not to know?: realist and liberal theories on foreign affairs and public opinion in Latin America'. Latin American Policy, 6(1): 2-18.

Mouron, Fernando and Francisco Urdinez. 2016. 'Framing effects on foreign policy: experimental evidence from emerging countries - the Argentine-Brazilian rivalry'. Revista de Opinião Publica, 22(1).

Nederhof, Anton J. 1985. 'Methods of coping with social desirability bias: a review'. European Journal of Social Psychology, 15(3): 263-280.

Nolte, Detlef. 2010. 'How to compare regional powers: analytical concepts and research topics'. Review of International Studies, 36(4): 881-901.

Pinheiro, Leticia and Gabrieli Gaio. 2014. 'Cooperation for development, Brazilian regional leadership and global protagonism'. Brazilian Political Science Review, 8(2): 8-30.

Russell, Roberto and Juan Tokatlian. 2011. 'Percepções argentinas sobre o Brasil: ambivalências e expectativas'. In Bernardo Sorj and Sergio Fausto (eds). Brasil e a América do Sul: Olhares Cruzados. Rio de Janeiro: Plataforma Democrática: 247-274.

Santos, Sergio C. 2011. 'Brasil y la región: una potencia emergente y la integración regional sudamericana'. Revista Brasileira de Política Internacional, 54(2): 158-172.

Saraiva, Miriam G. 2010. 'Brazilian foreign policy towards South America during the Lula Administration: caught between South America and Mercosur'. Revista Brasileira de Política Internacional, 53 (SPE): 151-168.

.2012. 'Procesos de integración de América del Sur y el papel de Brasil: los casos del Mercosur y la Unasur/Integration processes in South America and the role of Brazil: the cases of Mercosur and Unasur'. Revista CIDOB d'Afers Internacionals, 98(1): 87-100.

Schenoni, Luis L. 2012. 'Rise and hegemony: some observations on emerging powers from a South American perspective'. Revista Brasileira de Política Internacional, 55(1): 31-48. 


\section{Latin American Perceptions of Regional Identity and Leadership in Comparative...}

Schirm, Stefan A. 2012. 'Leaders in need of followers: emerging powers in global governance'. In Power in the 21st Century. Berlin: Springer: 211-236.

Sobel, Richard. 2001. The Impact of Public Opinion on US Foreign Policy since Vietnam: Constraining the Colossus. New York: Oxford University.

Sorj, Bernardo and Sergio Fausto. 2011. 'Brazil and South America: contrasting perspectives’. Plataforma Democrática, Working Paper no 12. Available at http://www.bernardosorj.org/ [accessed on 12 October 2015]

Souza, Amaury. 2009. A Agenda Internacional do Brasil. Rio de Janeiro: Editora Campus/CEBRI.

Spektor, Matías. 2010. 'Ideias de ativismo regional: a transformação das leituras brasileiras da região’. Revista Brasileira de Política Internacional, 53(1): 25-44.

Teixeira, Carlos G P. 2011. 'Brazil and the institutionalization of South America: from hemispheric estrangement to cooperative hegemony'. Revista Brasileira de Política Internacional, 54(2): 189-211.

Trinkunas, Harold. 2014. 'Brazil's rise: seeking influence on global governance'. Latin American Initiative, Foreign Policy at Brookings. Available at http://calhoun.nps.edu/handle/10945/43088 [accessed on 15 September 2015].

Varas, Augusto. 2008. 'Brazil in South America: from indifference to hegemony'. FRIDE. Available at http://fride.org/download/COM_Brazil_ Sudamerican_ENG.pdf [Accessed on 10 September 2015]

Vigevani, Tullo and Gabriel Cepaluni. 2007. 'A política externa de Lula da Silva: a estratégia da autonomia pela diversificação'. Contexto internacional, 29(2): 273-335.

Wehner, Leslie E. 2015. 'Role expectations as foreign policy: South American secondary powers' expectations of Brazil as a regional power'. Foreign Policy Analysis, 11(4): 435-455.

Wendt, Alexander. 1999. Social Theory of International Politics. Cambridge: Cambridge University Press.

Winand, Érica. C A. 2015. 'A rivalidade como sentimento profundo: origem, evolução histórica e reflexos contemporâneos do padrão de rivalidade entre Brasil e Argentina'. História e Cultura, 4(1): 68-95. 


\section{Janina Onuki, Fernando Mouron and Francisco Urdinez}

\section{Appendix I}

In order to capture respondents' sense of belonging to a Latin American region, the survey in the six Spanish-speaking countries asked: ‘QQué se siente usted más? In Portuguese-speaking Brazil, it asked: 'Que é o que o senhor se sente mais?'. In both cases, this translates as: 'What do you feel most like?'

\section{Appendix II}

In order to capture Brazilians' level of approval of their government's foreign policy, the survey asked: 'Você diria que concorda totalmente, concorda em parte, discorda em parte ou discorda totalmente com o desempenho do governo brasileiro em matéria de politica exterior?' This translates as: 'Do you totally agree, partially agree, partially disagree or totally disagree with the Brazilian government's performance in foreign policy?'

\section{Appendix III}

In order to capture Brazilians' level of approval of their government's performance, the survey asked: 'Você diria que concorda totalmente, concorda em parte, discorda em parte ou discorda totalmente com o desempenho do governo brasileiro?' This translates as: 'Do you you totally agree, partially agree, partially disagree or totally disagree with the Brazilian government's performance?'

\section{Appendix IV}

In order to determine which region respondents believed their country should prioritise, the survey in the six Spanish-speaking countries asked: ‘'A qué region del mundo su país debe prestar más atención?'. In Brazil, it asked: 'A qual região do mundo o Brasil 
deveria prestar maior atenção?'. In both cases, this translates as: 'To which world region should you country pay more attention?' The options were: North America, Latin America, Europe, Asia, the Middle East, Africa and Oceania.

\section{Appendix V}

In order to determine whether Brazilians believed their country should intervene militarily in a regional crisis, the survey asked: 'Você concorda ou discorda sobre a seguinte frase: Ocorreu um conflito militar na fronteira entre dois países da América do Sul. O Brasil não se envolveu na crise'. This translates as: "Do you agree or disagree with the following sentence: There was a military conflict on the border between two South American countries. Brazil did not get involved in the crisis.' The options were: totally disagree. somewhat disagree, neither agree nor disagree, somewhat agree, totally agree.

\section{Appendix Vı}

In order to ascertain whether Brazilians agreed with their country helping less developed nations in the region, the Brazilian survey asked: 'Quanto você concorda ou discorda com que o Brasil ajude a paises menos desenvolvidos da região?’ In the six Spanish-speaking countries, the survey asked: ‘Qué tan de acuerdo o en desacuerdo está con que su país ayude a países menos desarrollados de la región?'. In both cases, this translates as: 'To what extent do you agree or disagree with Brazil helping less developed countries in the region?' The options were: totally disagree, somewhat disagree, neither agree nor disagree, somewhat agree, totally agree. 


\section{Janina Onuki, Fernando Mouron and Francisco Urdinez}

\section{Appendix VII}

In order to ascertain whether Brazilians agreed with the free movement of people among Latin American countries, the survey asked: 'Em relação à integração na America do Sul, você concorda ou discorda que haja livre movimento de pessoas na região sem controles fronteiriços?' This translates as: 'With regard to South American integration, do you agree or disagree that people should move about freely in the region without border controls?' The options were: totally disagree, somewhat disagree, neither agree nor disagree, somewhat agree, totally agree.

\section{Appendix VIII}

In order to ascertain which country should represent Latin America in the UN Security Council, the survey in the six Spanish-speaking countries asked: 'Si el Consejo de Seguridad de la Organización de las Naciones Unidas pudiera tener un nuevo asiento para representar a América Latina en su conjunto, ¿qué país debería ocupar ese asiento?'. In Brazil, the survey asked: 'Se o Conselho de Segurança das Nações Unidas tivesse uma nova vaga para que um país representar a America Latina, qual país deveria ocupar esse lugar? In both cases, this translates as: 'If the UN Security Council had a new seat for a country representing Latin America as a whole, which country should occupy that seat?' This was an open-ended question, and no options were provided.

\section{Notes}

1. The data will appear in the $2014 / 2015$ edition of the series of publications emanating from this project. 


\section{Latin American Perceptions of Regional Identity and Leadership in Comparative...}

2. The following institutions were involved in the project: Universidad de San Andrés (Argentina); Instituto de Relações Internacionais da Universidad de São Paulo (Brazil); Universidad de Chile (Chile); Universidad de los Andes (Colombia); Facultad Latinoamericana de Ciencias Sociales (Ecuador); Centro de Investigación y Docencia Económicas (México); Universidad Católica del Perú (Perú).

3. The samples were geographically representative of rural and urban populations, and socioeconomic variables such as class and income were also taken into account. A total of 10544 interviews were conducted, comprising the following: Argentina ( $\mathrm{N}=1$ 030), Brazil ( $\mathrm{N}=1881)$, Chile $(\mathrm{N}=1206)$, Colombia ( $N=1500)$, Ecuador ( $N=1800)$, Mexico ( $N=2400)$, and Peru ( $N=1200)$.

4. Data from previous surveys have been utilised in Morales Castillo, Maldonado and Schiavon (2015), but at the time of writing the data from the latest survey had not yet been published.

5. The best example is Simon Bolivar's 'Jamaica Letter' of 1815.

6. According to an IBOPE project released in September 2015, Dilma Rousseff's administration is only regarded positively by $10 \%$ of Brazilians, while $68 \%$ evaluated it as 'fair' or 'poor'.

7. According to the Brazilian Institute of Geography and Statistics, in 2013 about 87 million people in Brazil had access to the internet. For more information, see http://www.brasil.gov.br/infraestrutura/2014/09/ ibge-metade-dos-brasileiros-teve-acesso-a-internet-em-2013.

8. In all seven countries, the surveys asked: 'What is better for the future of your country? Active participation in worldwide affairs, or remaining distant from international politics? Responses in favour of active participation were as follows: Argentina (74\%), Brazil (76.5\%), Chile (67\%), Colombia (75.5\%), Ecuador (77.2\%), Mexico (60.6\%), Peru (72.7\%).

9. Examples are questions related to discrimination, sexual misconduct, and the use of drugs. For a recent review, see Krumpal (2011).

10. According to the UN Development Programme, in 2012 Brazil's score on the Human Development Index was 0,74. Better scores in other Latin American countries were Mexico $(0,75)$, Venezuela $(0,75)$, Uruguay $(0,79)$, Argentina $(0,80)$, Cuba $(0,81)$ and Chile $(0,82)$.

11. Statistics provided by the Brazilian Institute of Geography and Statistics.

12. Every four years, the Argentinian Council for International Relations conducts a representative public opinion survey on international affairs and 
Janina Onuki, Fernando Mouron and Francisco Urdinez

foreign policy issues. In 2010, when asked which Latin American country would be most relevant in the international arena in the next decade, $25 \%$ of respondents chose Brazil as their first option. For more information, see http://www.cari.org.ar/pdf/encuesta2010.pdf.

13. Brazil has long sought to become a full member of the OECD. Although significant steps were taken in 2015 to create a closer working relationship with the OECD, Brazil's poor economic performance from 2014 onwards were delaying its entrance.

\section{About the authors}

Janina Onuki is academic co-ordinator of the Centre for Advanced Studies in International Negotiations at the University of São Paulo, and senior professor at the Institute of International Relations at the same university. She holds a PhD in political science from the University of São Paulo. She was previously a visiting professor in public and international affairs at North Carolina State University. She edits the Brazilian Political Science Review. Her research focuses on foreign policy analysis, international regimes and regional integration. The one is funded by the Brazilian National Council for Scientific and Technological Development (CNPq) and the São Paulo Research Foundation (FAPESP).

Fernando Mouron is a research fellow at the Centre for Advanced Studies in International Negotiations at the University of São Paulo, and a $\mathrm{PhD}$ candidate under the joint degree programme of the University of São Paulo and King's College, London. His research focuses on Latin American perceptions of Brazilian regional leadership, and the interaction between public opinion and foreign policy. He has recently published articles in the Brazilian Political Science Review (2014), Estudos Internacionais (2015), Revista CIDOB d'Afers Internacionals (2016), and Revista de Opinião Publica (2016). He has held scholarships from the Brazilian National Council for Scientific and Technological Development (CNPq), and is currently a São Paulo Research Foundation (FAPESP) scholar. www.fernandomouron.com 


\section{Latin American Perceptions of Regional \\ Identity and Leadership in Comparative...}

Francisco Urdinez is a research fellow at the Centre for Advanced Studies in International Negotiations at the University of São Paulo, and a PhD candidate under the joint degree programme of the University of São Paulo and King's College, London. His research focuses on Latin American relations with China and the United States. He maintains an interest in the use of quantitative methodology in studying international relations. He has received scholarships from the Fulbright Commission and the Brazilian National Council for Scientific and Technological Development (CNPq) and is currently a São Paulo Research Foundation (FAPESP) scholar. www.furdinez.com 